\title{
New Paleocene bird fossils from the North Sea Basin in Belgium and France
}

\author{
GERALD MAYR $^{1^{*}} \&$ THIERRY SMITH ${ }^{2}$
}

\author{
${ }^{1}$ Senckenberg Research Institute and Natural History Museum Frankfurt, Ornithological Section, Senckenberganlage 25, D-60325 \\ Frankfurt am Main, Germany; Gerald.Mayr@senckenberg.de. \\ ${ }^{2}$ Royal Belgian Institute of Natural Sciences, Directorate Earth \& History of Life, Rue Vautier 29, B-1000 Brussels, Belgium; thierry. \\ smith@naturalsciences.be. \\ * corresponding author.
}

\begin{abstract}
We describe new avian remains from Paleocene localities of Belgium and France. Four bones from the early to middle Selandian of Maret (Belgium) are among the earliest Cenozoic avian remains known from Europe and include the oldest temporally well constrained European records of the Gastornithidae, as well as tentative records of the palaeognathous Lithornithidae and the Ralloidea. A more comprehensive fossil assemblage from the middle Thanetian of Templeuve (France) contains multiple bones of the Lithornithidae as well as a record of the Pelagornithidae. Specimens from the latest Thanetian of Rivecourt-Petit Pâtis (France) are tentatively assigned to the Ralloidea and Leptosomiformes (cf. Plesiocathartes). Because of the fragmentary nature of the fossils, the taxonomic identity of a number of other specimens remains uncertain. We note, however, that Paleocene avifaunas of Europe and North America appear to have had different compositions and only a few taxa, such as the palaeognathous Lithornithidae, are known from both continents. This suggests that the very similar early Eocene avifaunas of Europe and North America are the result of early Cenozoic dispersal events.
\end{abstract}

KEYWORDS: bird evolution, fossil birds, K/Pg extinction, Selandian, Thanetian.

\section{Introduction}

Europe has a comparatively rich and well-studied Eocene avian fossil record, but bird remains from the Paleocene period are very scant (Mayr, 2009, 2017a, b; Mayr et al., 2019a). The exact age of some localities is furthermore controversially discussed, which impedes well-founded biogeographic inferences.

The Paleocene is divided into three stages, the Danian (66.0-61.6 million years ago [Ma]), Selandian (61.6-59.2 Ma), and Thanetian (59.2-56.0 Ma). With the exception of Scaniornis lundgreni from the Danian of Sweden - a bird of uncertain phylogenetic affinities that is only known from the poorly preserved wing bones of the holotype (Dames, 1890) -, all bird fossils from the Paleocene of Europe stem from the Selandian and Thanetian stages.

Already in the $19^{\text {th }}$ century, fossils of the large flightless Gastornithidae were described from the late Thanetian ( $\sim 57.5 \mathrm{Ma})$ localities Cernay-lès-Reims and Mont-de-Berru in the eastern Paris Basin in France (Lemoine, 1878, 1881; Martin, 1992; Buffetaut, 1997; Mourer-Chauviré \& Bourdon, 2016). Equally long known from these sites is the palaeognathous taxon Remiornis, whereas the description of other avian remains from the Mont-de-Berru area commenced much later (MourerChauviré, 1994, 1995). This is also true for bird fossils from the fissure fillings of Walbeck in Germany, which were found in the first half of the $20^{\text {th }}$ century, but have been described more than 70 years later (Mayr, 2002a, 2007). Even on a global scale, the bird assemblage from Walbeck represents the most comprehensive Paleocene avifauna known so far. The age of the sediments from Walbeck has long been controversial, but based on a comparison of the mammalian remains, it has been concluded that the strata are coeval to those from the Selandian Belgian locality Maret (De Bast et al., 2013). Likewise known since the first half of the $20^{\text {th }}$ century are recently described avian fossils from the Selandian ( 60-61 Ma) of Menat in France (Mayr et al., 2019a).

Bird remains from the Paleocene of Belgium, which are housed in the collection of the Royal Belgian Institute of Natural Sciences, Brussels, were mentioned by Misonne (1958) and Cheneval (1996). These fossils include a distal femur of a species of the Gastornithidae from mid-Thanetian (NP8 biozone; $\sim 58 \mathrm{Ma}$; Anthonissen \& Ogg, 2012) marine strata of Mesvin, which was described by Dollo (1883). Bird bones from the mid to late Selandian (NP5 biozone; $60 \mathrm{Ma}$; De Bast et al., 2013) of Gelinden, which were listed by Misonne (1958) and Cheneval (1996), represent featureless fragments and defy an identification and meaningful description. However, as yet undescribed fossils from Maret (early to middle Selandian) are more diagnostic and complemented by recent finds of private collectors. These specimens are described in the present study. We further report avian remains from two Paleocene localities of the North Sea Basin in France, Templeuve (middle Thanetian) and Rivecourt (latest Thanetian). As detailed below, some of the specimens reported herein are the earliest fossil records of avian higherlevel clades, and all add to a better understanding of Paleocene European avifaunas.

\section{Geological setting}

The strata of Maret, a hamlet of the village Orp-le-Grand at mid distance between Brussels and Liège (Belgium; Fig. 1), belong to the early to middle Selandian (upper NP4-NP5 biozone; $\sim 61 \mathrm{Ma}$ ) Orp Sand Member of the Heers Formation (Fig. 2; see De Bast et al., 2013). They originated in a shallow marine environment, and have yielded only a few remains of terrestrial mammals. Bird fossils are likewise very rare, but unidentified avian remains from Maret were already mentioned by Misonne (1958) and Cheneval

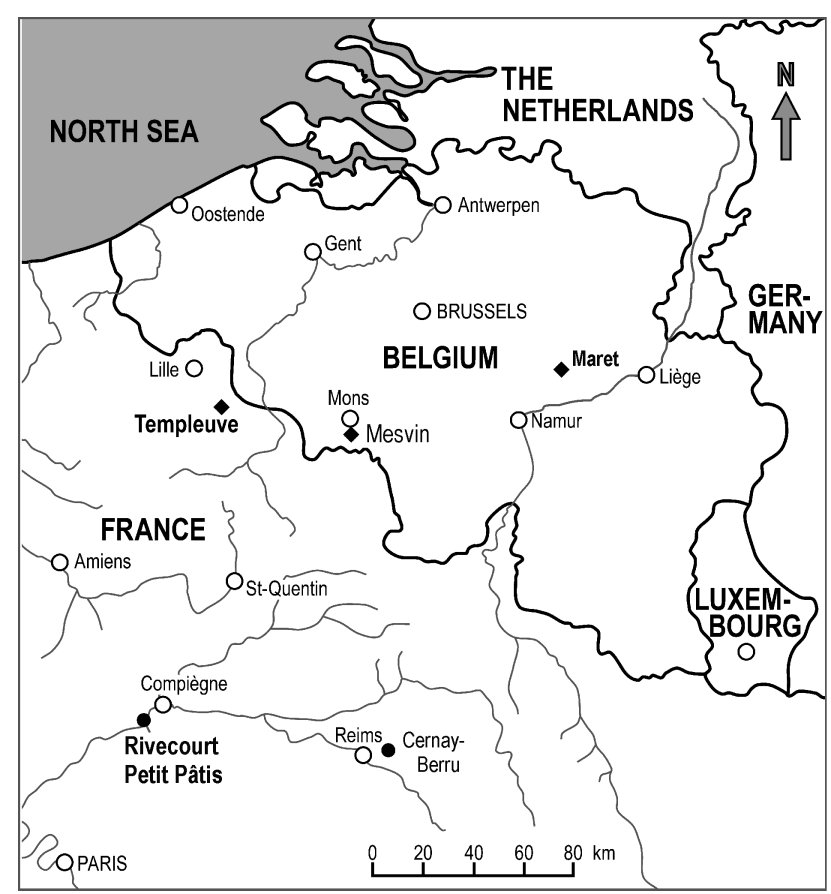

Figure 1. Map with the Paleocene vertebrate localities in Belgium and Northern France that yielded fossil birds. The filled circles indicate terrestrial sites, the diamonds marine ones. New specimens described in the present study are from localities in bold. 
(1996). As yet, none of these specimens have been figured or described.

The fossils from Templeuve near Lille (Département du Nord, France; Fig. 1) are from the middle Thanetian (NP8 biozone; $\sim 58 \mathrm{Ma}$ ) Tuffeau de Saint-Omer (Fig. 2; see Steurbaut, 1998, fig. 9; Moreau \& Mathis, 2000; Smith \& Smith, 2003). The strata of this locality are of marine origin and yielded a diverse assemblage of elasmobranch teeth (Moreau \& Mathis, 2000); avian remains are for the first time reported in the present study.

The fluviatile sediments of the Petit Pâtis quarry at Rivecourt near Compiègne in the north-central part of the Paris Basin (Département de l'Oise, France; Fig. 1) stem from the latest Thanetian (Fig. 2; "basal Sparnacian facies", upper NP9 biozone; $\sim 56.5 \mathrm{Ma}$ ), and the locality was identified as a temporal equivalent of the Clarkforkian North American Land Mammal Age (Smith et al., 2014). The most abundant tetrapod fossils found are mammals, turtles, and champsosaurs (Smith et al., 2014). Remains of crocodilians, urodeles, lizards, and snakes are much rarer. The presence of birds at Rivecourt was already noted by Smith et al. (2014), who identified large fragmentary vertebrae of a putative palaeognathous bird (cf. Remiornithidae) and of an unidentified species of the large, flightless Gastornithidae (see also Buffetaut \& Angst, 2014).

\section{Material and methods}

Osteological terminology follows Baumel \& Witmer (1993). Institutional abbreviations: IGWuG - Institut für Geologische Wissenschaften und Geiseltalmuseum of Martin-LutherUniversität Halle-Wittenberg, Halle/Saale, Germany; IRSNB Royal Belgian Institute of Natural Sciences, Brussels, Belgium; MAV - Musée Antoine Vivenel, Compiègne, France; NHMUK - Natural History Museum, London, UK; SMF - Senckenberg Research Institute Frankfurt, Germany.

\section{Systematic Paleontology}

\subsection{Specimens from Maret (Belgium, early to middle Selandian, $\sim 61 \mathrm{Ma}$ )}

Gastornithidae Fürbringer, 1888

Gastornis Hébert, 1855

Gastornis sp.

(Figs 3A-C)

Referred specimen. IRSNB Av 213: right femur lacking the proximal and most of the distal end (old collection).

Measurements. Length as preserved, $158 \mathrm{~mm}$; estimated total length, $200 \mathrm{~mm}$; estimated distal width, $\sim 55 \mathrm{~mm}$.

Remarks. This fossil is very fragmentary and mainly consists of the shaft and the medial portion of the distal end. The only major osteological feature visible is a marked fossa on the medial surface of the distal end. The size and stoutness of the bone indicates that it is from a large flightless bird and suggests a referral to the Gastornithidae, which is the only avian taxon of comparable size known from the Paleocene of Europe. With an estimated distal width of about $55 \mathrm{~mm}$, the specimen is too large to correspond to the tibiotarsus of the only other large-sized avian taxon known from the Paleocene of Europe, the palaeognathous Remiornis heberti, whose proximal tibiotarsus has an estimated width of 35-40 mm (Martin, 1992, fig. 9).

We estimate a total length of about $200 \mathrm{~mm}$ for the bone. The specimen is therefore from a species that was much smaller than the large late Paleocene to middle Eocene species of Gastornis, whose femora have a length between 295 and $380 \mathrm{~mm}$ (Fischer, 1978; Figs 3D, E). In size, it corresponds best with Gastornis russelli from the Thanetian deposits of the Mont-de-Berru area (Martin, 1992), of which, however, only the tarsometatarsus and a beak fragment are known. The tarsometatarsus of G. russelli has

\section{Belgium}

(n)

Figure 2. Consensus correlation of the main Paleocene stratigraphic units of Belgium and Northern France. Deposits that yielded fossil birds are light shaded. Abbreviations: NP: Calcareous nannofossil zonation for the Paleogene; MP: reference-level of the Mammal biochronological scale for the European Paleogene; Fm., Formation; Mb., Member; congl., conglomerate. Stratigraphic data and correlations were compiled from Berggren \& Aubry (1996), Steurbaut (1998), Smith \& Smith (2003), Aubry et al. (2005), Anthonissen \& Ogg, (2012), Vandenberghe et al. (2012), and Smith et al. (2014). Localities in bold yielded the specimens that are described in the present study. 

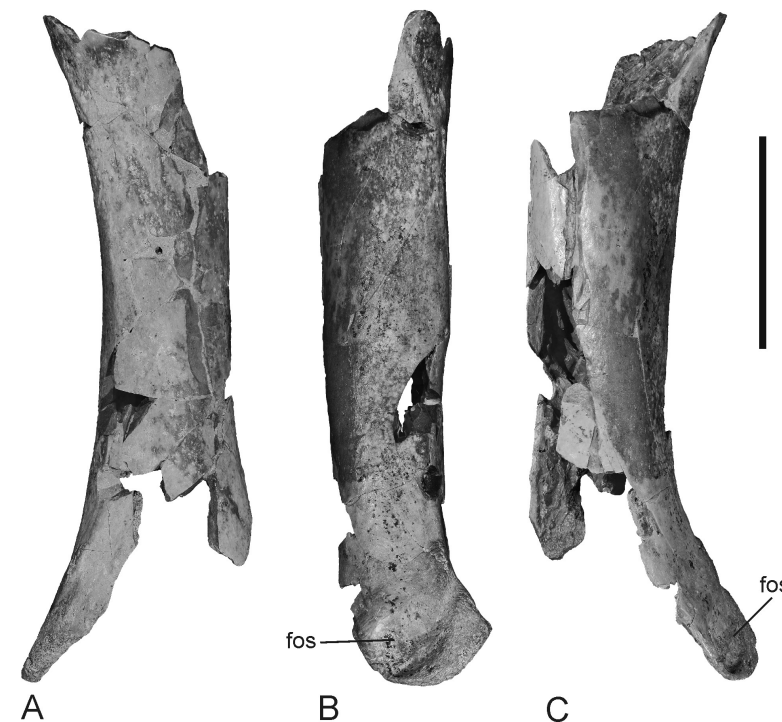

C

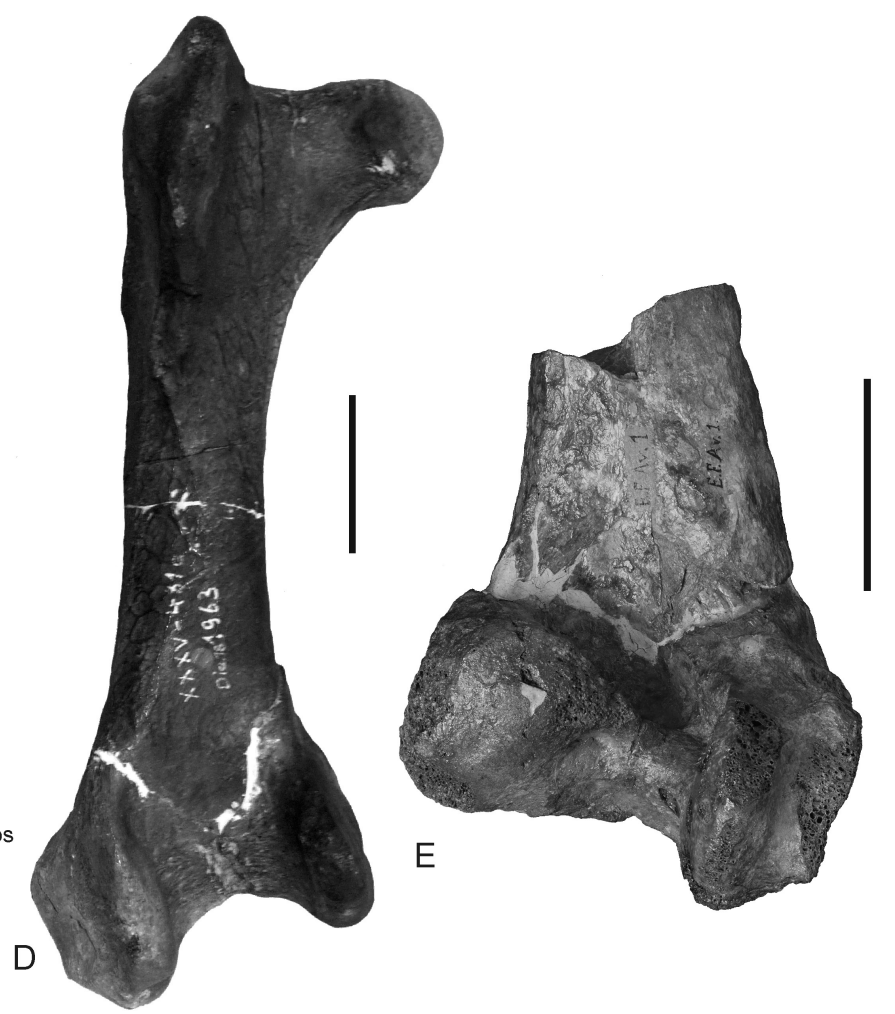

Figure 3. A-C, Fragmentary right femur of a putative gastornithid (IRSNB Av 213) from the early to middle Selandian of Maret (Belgium) in caudal (A), medial (B) and cranial (C) view. D, right femur (cranial view) of Gastornis geiselensis from the middle Eocene of the German locality Geiseltal (IGWuG XXXV-481a-1963). E, Distal end (caudal view) of a right gastornithid femur from the mid-Thanetian of Mesvin in Belgium (IRSNB Av 1); this specimen was described as Gastornis edwardsii by Dollo (1883), with this species now being considered a junior synonym of G. parisiensis (Martin, 1992). Abbreviation: fos, fossa on medial surface of distal end. Scale bars equal $50 \mathrm{~mm}$.

a length of $129 \mathrm{~mm}$ (Martin, 1992), whereas the bone measures 267 and $303 \mathrm{~mm}$ in two individuals of G. parisiensis, another very large Gastornis species from the Mont-de-Berru area. This relative size difference of $43-48 \%$ corresponds with the size difference of $53-68 \%$ that exists between the length of the femur from Maret and those of large Eocene gastornithids.

An equally small gastornithid species was reported from Walbeck, where it is only represented by a coracoid (Mayr, 2007). Because the specimens from Maret, Walbeck, and the Mont-deBerru area are known from different skeletal elements, it cannot be said whether they belong to the same species. However, a small size is likely to be plesiomorphic for gastornithids (Mayr, 2009), and whereas only very large-sized gastornithid species are known from the early Eocene, a greater diversity of small gastornithids may have existed in the mid-Paleocene.

\section{cf. Lithornithidae Houde, 1988}

Gen. et sp. indet.

(Figs 4A-D)

Referred specimens. IRSNB Av 214: fragmentary portion of left distal humerus (collected by Pieter De Schutter). IRSNB Av 215: proximal end of right carpometacarpus (collected by Guy Van Den Eeckhaut).

Measurements. Carpometacarpus (IRSNB Av 215), length as preserved, $16.7 \mathrm{~mm}$. Humerus (IRSNB Av 214), width as preserved, $13.4 \mathrm{~mm}$.

Remarks. Even though these fossils are very fragmentary, they closely resemble the more complete and diagnostic specimens of the palaeognathous Lithornithidae from Templeuve, which are described further below. The carpometacarpus in particular shows the characteristic morphology of the lithornithid carpometacarpus (Nesbitt \& Clarke, 2016, fig. 34C) in that there is a marked fossa infratrochlearis, which excavates the processus pisiformis, and in that there is another fossa caudal of the processus pisiformis. As in lithornithids (Nesbitt \& Clarke, 2016, fig. 15), the fovea carpalis caudalis is likewise well marked and very deep. The tip of the processus extensorius, which is abraded or broken in the specimens from Templeuve, forms an essentially flat platform that is offset from the process by a rim. Unlike in most neognathous birds, the articular surface of the processus alularis is deeply concave.

The fragmentary humerus likewise corresponds with a distal humerus from Templeuve in that the proximal end of the condylus dorsalis forms a marked step, whereas this condyle has an evenly convex surface in most other birds. In contrast to most neognathous birds, there is no well-delimited sulcus scapulotricipitalis.

\section{cf. Ralloidea Vigors, 1825 \\ Gen. et sp. indet.}

(Figs 4E-G)

Referred specimen. IRSNB Av 216: distal end of left tarsometatarsus (collected by Philippe Garot).

Measurements. Length as preserved, $8.0 \mathrm{~mm}$; distal width, $4.9 \mathrm{~mm}$

Remarks. In overall morphology, this fossil most closely resembles the tarsometatarsus of the Ralloidea (rails, sungrebes, and allies). The trochlea metatarsi II is plantarly deflected and its distal end reaches distally to about the level of the middle of the trochlea metatarsi IV. In plantar and dorsal view, the trochlea metatarsi III widens towards its distal end; its plantar articulation surface is slightly asymmetric, with the lateral rim being somewhat longer than the medial one. The incisura intertrochlearis lateralis is wide and has a "keyhole-like" shape with an expanded proximal section. A fossa metatarsi I is absent, which indicates a poorly developed hallux. The foramen vasculare distale is comparatively large; a canalis interosseus distalis is present.

Several extinct taxa are known from the Paleocene of Europe, which show a resemblance to the Ralloidea (Mayr, 2009, 2017a). The fossil from Maret is much larger than the species of the ralloid taxon Songzia. This latter taxon was originally described from the early Eocene of China (Wang et al., 2012), but may also be present in Menat (Mayr et al., 2019a). Another ralloid taxon, the Messelornithidae, is very abundant in some early and 

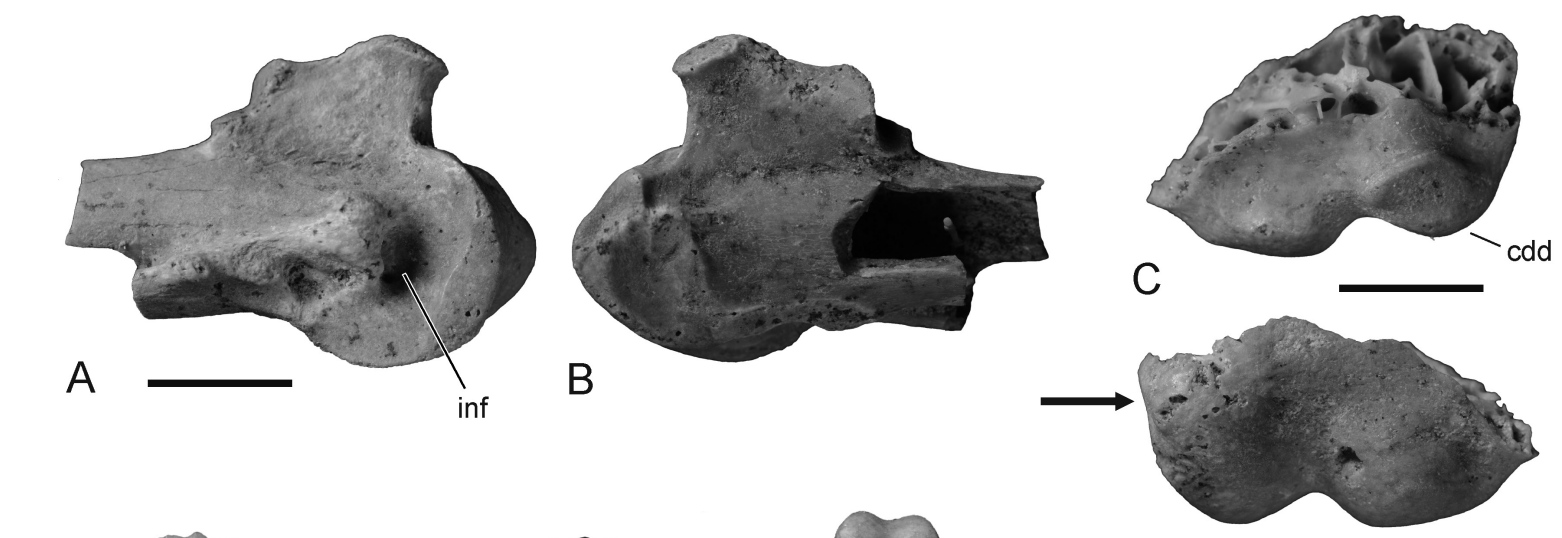

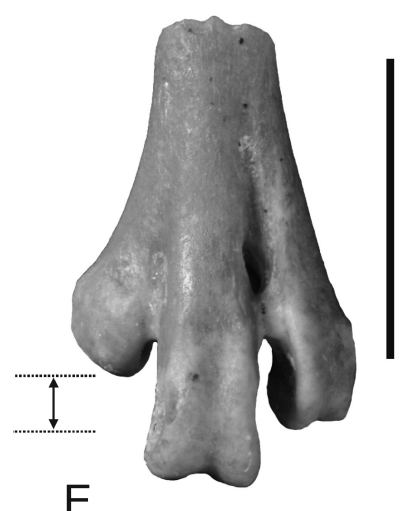

E

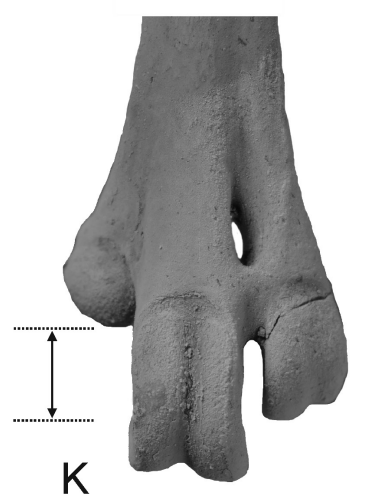

Messelornithidae

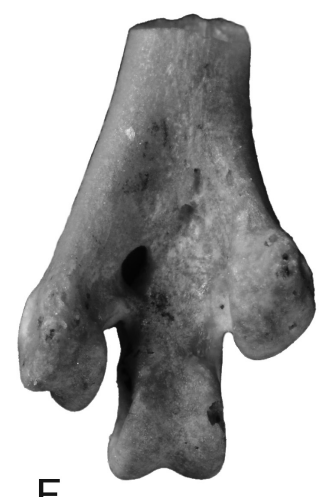

F

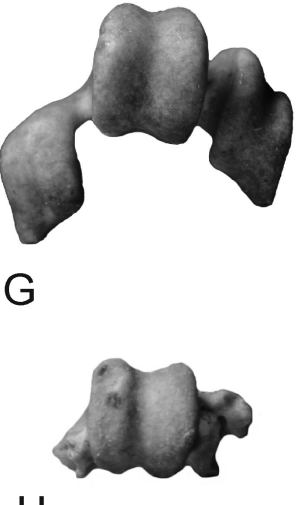

$\mathrm{H}$

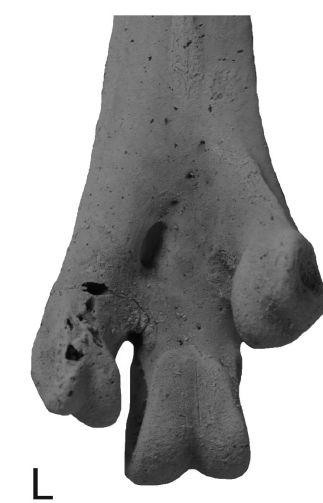

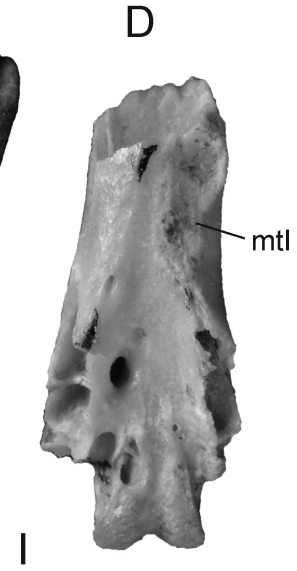

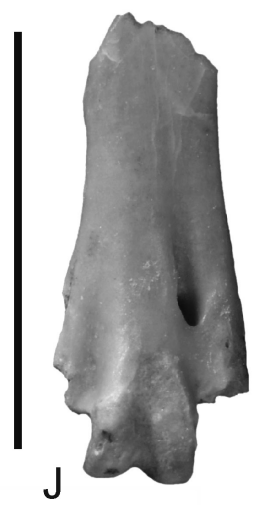

M

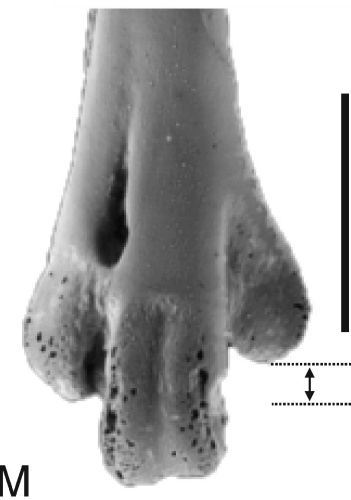

\section{Walbeckornis}

Figure 4. Further avian remains from the early to middle Selandian of Maret (Belgium), as well as fossils of the Messelornithidae from Egem (Belgium) and Walbeckornis from Walbeck (Germany). A, B, Proximal end of a right carpometacarpus (IRSNB Av 215) that is tentatively referred to the palaeognathous Lithornithidae in ventral (A) and dorsal (B) view. C, D, fragmentary distal portion of a left humerus (IRSNB Av 214 ) that is tentatively referred to the palaeognathous Lithornithidae in cranial (C) and caudal (D) view; the arrow denotes the absence of a well-delimited sulcus scapulotricipitalis. E-G, distal end of a left tarsometatarsus that is tentatively assigned to the Ralloidea (IRSNB Av 216) in dorsal (E), plantar (F), and distal (G) view. H-J, Aves indet., species A, distal end of left tarsometatarsus lacking trochleae metatarsorum II and III (IRSNB Av 217) in distal (H), plantar $(\mathrm{G})$ and dorsal $(\mathrm{H})$ view. K, L, distal end of the left tarsometatarsus of a messelornithid from the early Eocene of Egem (Belgium) in dorsal (K) and plantar (L) view (IRSNB Av 170; Mayr \& Smith, 2019). M, N, distal end of the right tarsometatarsus of Walbeckornis creber from the Selandian of Walbeck (Germany) in dorsal (M) and plantar (N) view (holotype; IGWuG WAL472.2007). The dotted lines in E, K, and M indicate the distance between the distal ends of the trochleae metatarsorum II and IV. Abbreviations: cdd, condylus dorsalis; inf, fossa infratrochlearis; mtI, fossa metatarsi I. Specimens in K-N were coated with ammonium chloride. Scale bars equal $5 \mathrm{~mm}$.

middle Eocene localities and has also been reported from the late Paleocene of the Mont-de-Berru area (Mourer-Chauviré, 1995). Compared with Messelornis - the best known taxon of messelornithids and the only one that has been reported from Paleocene strata -, the trochlea metatarsi II of IRSNB Av 216 reaches farther distally (in the Messelornithidae, this trochlea reaches only as far distally as the base of the trochlea metatarsi IV; Figs 4K, L). With regard to the relative length of the trochlea metatarsi II, the fossil from Maret more closely resembles the taxon Walbeckornis from Walbeck (Mayr, 2007), in which, however, the distance between the distal ends of the trochleae metatarsorum II and IV is even shorter than in IRSNB Av 216 (Figs 4M, N). The distal ends of the tarsometatarsus of the putatively gruiform taxon Wanshuina from the mid-Paleocene of China (Hou, 1994) is unknown, so that meaningful comparisons with the fossil from Maret are not possible.

Aves indet., species A

(Figs 4H-J)

Referred specimen. IRSNB Av 217: distal end of left tarsometatarsus lacking trochleae metatarsorum II and III 
(collected by Philippe Garot).

Measurements. Length as preserved, $5.7 \mathrm{~mm}$; width of trochlea metatarsi III, $1.3 \mathrm{~mm}$.

Remarks. This fossil is from a small species of about the size of an extant mousebird (Colius spp.). The fossa metatarsi I is large and distinct and forms a subcircular fossa in its proximal portion. A marked sulcus extensorius opens into the foramen vasculare distale, a canalis interosseus distalis is present. The trochlea metatarsi II is broken, but the breakage indicates that is was more plantarly deflected than the likewise broken trochlea metatarsi IV. Both, the dorsal and plantar surfaces of the shaft are comparatively flat, which suggests that both trochleae were only moderately deflected. The short trochlea metatarsi III is about as wide as it is long; in distal view, the mediolateral width of the trochlea exceeds its dorsoplantar depth.

The fragmentary preservation of the fossil impedes a reliable identification. The small size of the specimen and its overall shape correspond with the tarsometatarsi of some "higher landbirds" (e.g. Coliiformes), but any assignment to a particular clade would be highly speculative.

\subsection{Specimens from Templeuve (France, middle Thanetian, $\sim 58 \mathrm{Ma}$ )}

Lithornithidae Houde, 1988

Gen. et sp. indet.

(Fig. 5)

Referred specimens. IRSNB Av 218: right coracoid lacking extremitas omalis (collected by Guy Van Den Eeckhaut). IRSNB Av 219: proximal and distal ends of right humerus (collected by Gino Mariën). IRSNB Av 220: partial left carpometacarpus in two pieces (collected by Guy Van Den Eeckhaut). IRSNB Av 221: proximal end of left carpometacarpus (collected by Guy Van Den Eeckhaut). IRSNB Av 222: distal end of left tibiotarsus (collected by Guy Van Den Eeckhaut).

Tentatively referred specimens. IRSNB Av 223: right radius lacking distal tip (collected by Gino Mariën). IRSNB Av 224: distal portion of left os metacarpale majus of carpometacarpus (collected by Gino Mariën).

Measurements. Coracoid(IRSNB Av218), length as preserved, $25.7 \mathrm{~mm}$; sternal width as preserved, $19.5 \mathrm{~mm}$. Proximal humerus (IRSNB Av 219), length as preserved, $30.9 \mathrm{~mm}$; proximal width, $19.9 \mathrm{~mm}$. Distal humerus (IRSNB Av 219), length as preserved, $33.9 \mathrm{~mm}$; distal width, $15.7 \mathrm{~mm}$. Radius (IRSNB Av 223), length as preserved, $79.5 \mathrm{~mm}$; estimated total length $85-95 \mathrm{~mm}$. Carpometacarpus IRSNB Av 220, craniocaudal depth of tip of os metacarpale majus, $6.7 \mathrm{~mm}$. Carpometacarpus IRSNB Av 224 , craniocaudal depth of tip of os metacarpale majus, $8.0 \mathrm{~mm}$. Tibiotarsus (IRSNB Av 222), distal width, $11.7 \mathrm{~mm}$.

Remarks. The palaeognathous Lithornithidae are known from early Eocene sites in Europe and from the Paleocene and early Eocene of North America, and currently nine unambiguously identified species in four genus-level taxa (Lithornis, Pseudocrypturus, Paracathartes, and Calciavis) are distinguished (Houde, 1988; Nesbitt \& Clarke, 2016). A species from the Paleocene of Europe that was likened to the Lithornithidae is Fissuravis weigelti from Walbeck. This species is only known from the holotype coracoid, which differs in several aspects from the corresponding bone of typical lithornithids (Mayr, 2007).

The lithornithid bones from Templeuve are of matching size and may well belong to a single species. The omal extremity of the coracoid is broken, and near the breakage there is a small foramen nervi supracoracoidei. The bone has a very long processus lateralis, which characterizes the coracoid of the Lithornithidae. The facies interna of the crista articularis sternalis is delimited by a low ridge; the facies externa is hardly differentiated and only forms a small medial lip.

The proximal and distal fragments of the right humerus originally came from one bone that broke during collection (G. Mariën, pers. comm.). The bone is characterized by the poor development of the attachment sites for tendons and ligaments, and the proximal end closely resembles a lithornithid humerus from the Selandian (early Tiffanian, $\sim 59-60 \mathrm{Ma}$ ) of North
America, which was described by Stidham et al. (2014). The sulcus transversus merely is a short fossa. The fossa pneumotricipitalis is small, but deeply excavates the bone and forms an ovate opening. The tip of the tuberculum ventrale is broken, as is the tuberculum dorsale. The cranial surface of the bone forms a bulge next to the crista bicipitalis, which is, however, damaged in the specimen, in which only the raised base of this bulge is preserved. The distal end has a very indistinct sulcus scapulotricipitalis. The fossa musculi brachialis is shallow, but extends across most of the distal width of the bone. The processus flexorius is weakly projected distally, and it is less sharply delimited than in Paracathartes. The tuberculum supracondylare ventrale is proximodistally long.

The tentatively referred radius does not exhibit diagnostic features and its identification is merely based on size. The widening of the distal portion of the shaft shows that only a short distal section is missing.

The two carpometacarpi IRSNB Av 220 and IRSNB Av 221 show a similar morphology. The proximal end of the bone is characterized by a deep fossa infratrochlearis, which excavates the processus pisiformis. The fovea carpalis caudalis is very marked. Another distinct fossa is situated caudal of the pisiform process. On the dorsal surface of the os metacarpale majus, at the distal end of the bone, there are two sulci for the tendons of musculus interosseus dorsalis and $\mathrm{m}$. interosseus ventralis. The tentatively referred fragment of the os metacarpale majus (IRSNB Av 224) is slightly larger than the more complete carpometacarpus (IRSNB Av 220), but otherwise both bones exhibit a similar morphology.

Identification of the distal tibiotarsus is unambiguous. The bone exhibits a narrow and far medially situated sulcus extensorius. As in lithornithids and most extant palaeognathous birds, a pons supratendineus is absent (this osseous bridge is present in most Neognathae). The condyli are abraded in the fossil, so that no meaningful comparisons are possible.

All bones closely resemble the corresponding elements of the well-known taxon Lithornis, but these bones exhibit similar morphologies in lithornithids and most differences between Lithornis and the taxa Paracathartes, Pseudocrypturus, and Calciavis concern skeletal elements that are not preserved in the fossil assemblage from Templeuve. The distal width of the humerus IRSNB Av 219 (15.7 mm) corresponds with various lithornithid species, such as Lithornis celetius $(16.2 \mathrm{~mm})$ and Pseudocrypturus cercanaxius (13.5-15.2 $\mathrm{mm})$ from the late Paleocene and early Eocene of Wyoming (Houde, 1988, tab. 11). The width of the distal tibiotarsus agrees with that of Lithornis vulturinus from the early Eocene London Clay $(11.7 \mathrm{~mm}$ versus 11.2-11.4 mm in L. vulturinus; Houde, 1988, tab. 21). However, corresponding bone measurements are unknown from a number of other similar-sized species and there existed a considerable intraspecific size variation in lithornithids (Nesbitt \& Clarke, 2016). None of the lithornithid bones from Templeuve shows diagnostic features that are characteristic for a particular speciesor genus-level taxon.

\section{Pelagornithidae Fürbringer, 1888}

Gen. et sp. indet. (cf. Dasornis Owen, 1870)

(Figs 6A, B)

Referred specimen. IRSNB Av 225: distal end of left tarsometatarsus with broken trochleae (collected by Gino Mariën).

Measurements. Length as preserved, $36.0 \mathrm{~mm}$.

Remarks. This fossil represents the largest bird in the avian material from Templeuve. The specimen is characterized by an essentially flat plantar surface of the distal end at the base of the trochleae and a dorsally bulging trochlea metatarsi III. The foramen vasculare distale is large and a small canalis interosseus distalis is present. A fossa metatarsi I appears to be absent. In the preserved morphology, the specimen closely resembles an equally fragmentary tarsometatarsus of the distinctly smaller pelagornithid taxon Lutetodontopteryx from the middle Eocene of the Ukraine (Fig. 6C). In size, however, it approaches the tarsometatarsus of the very large Dasornis emuinus from the early Eocene London Clay, with this species having also been reported from the late Paleocene of Morocco (Bourdon et al., 2010). 


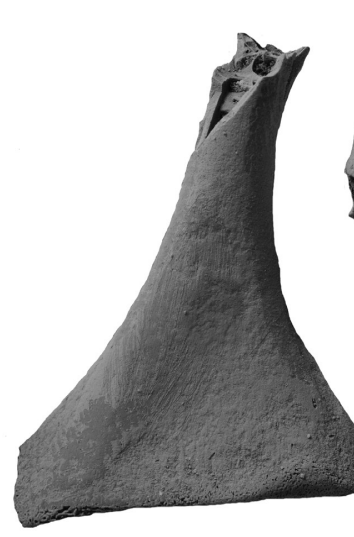

A

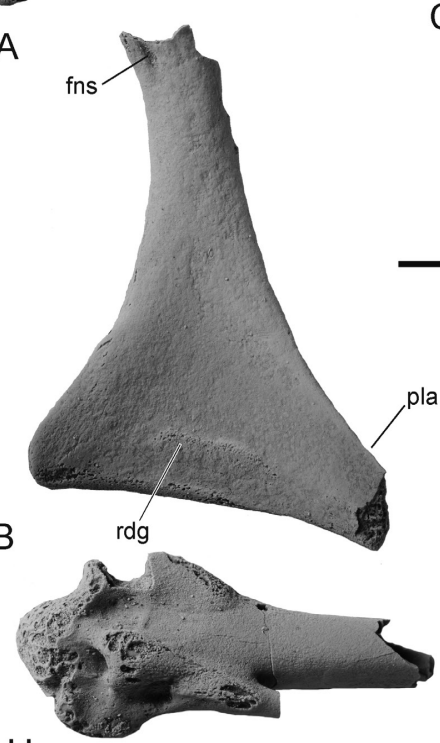

$\mathrm{H}$

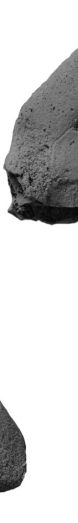

C
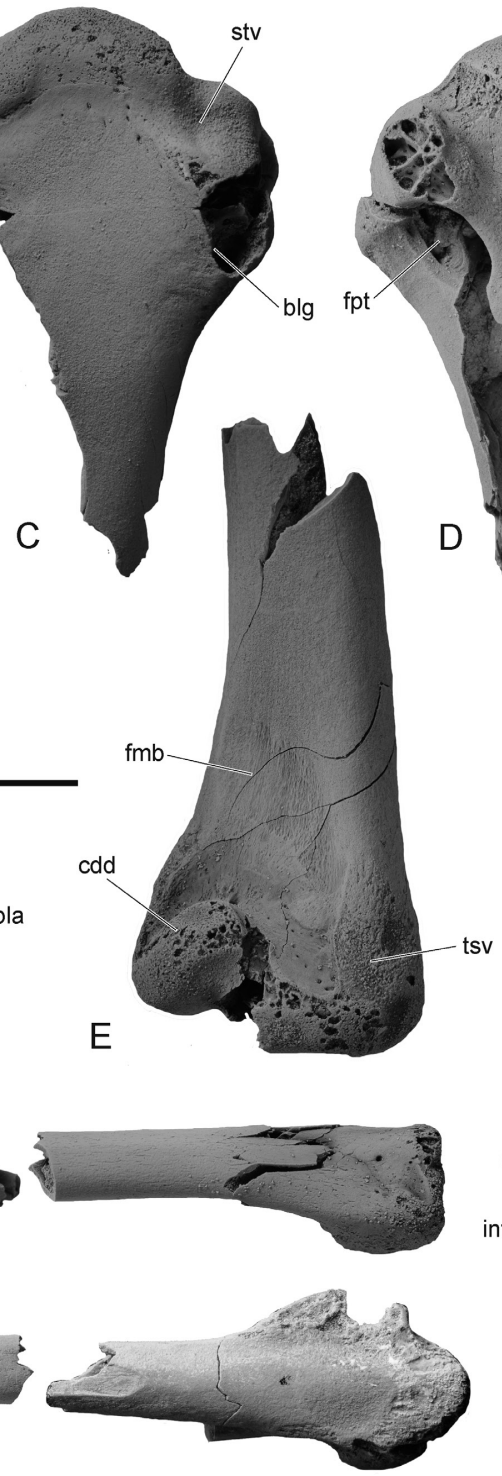

I
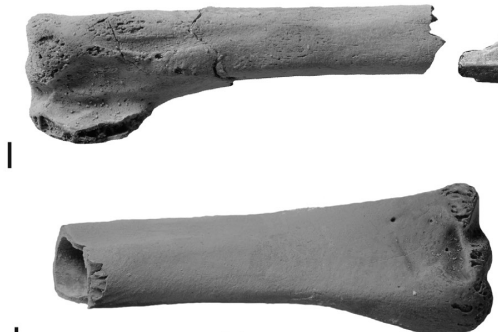

$\mathrm{L}$

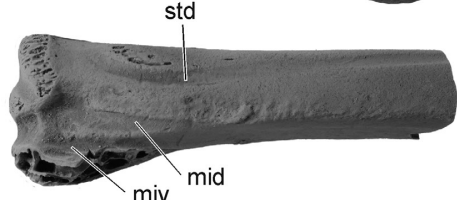

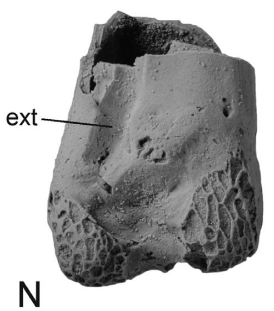
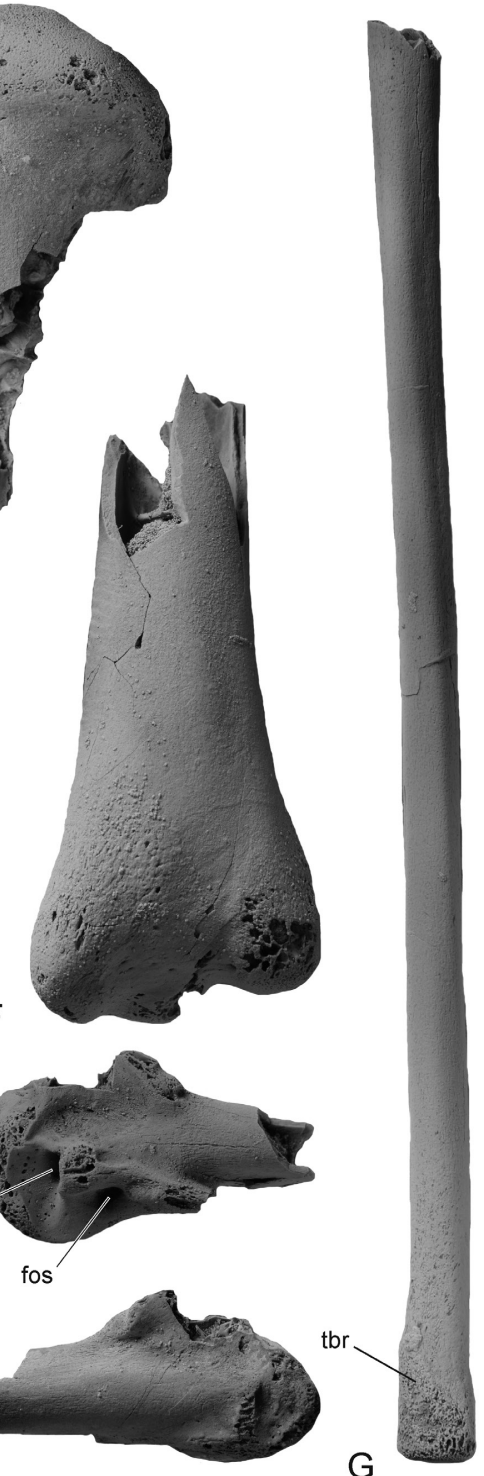

$\mathrm{K}$
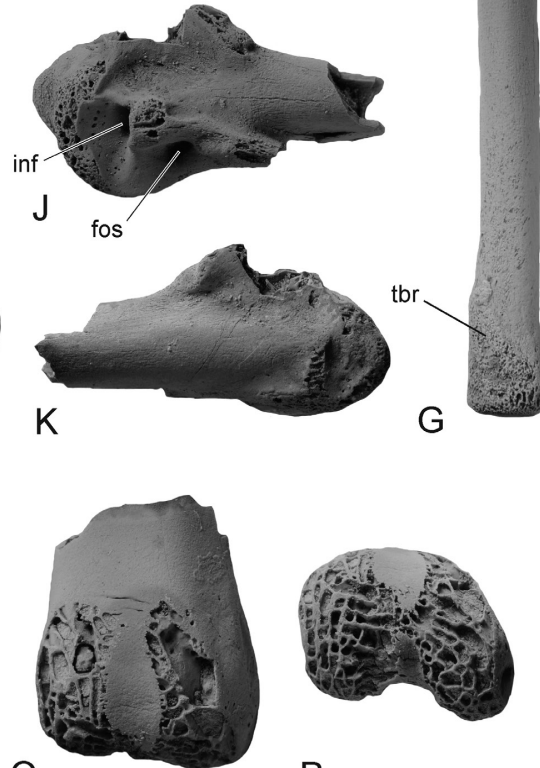

O

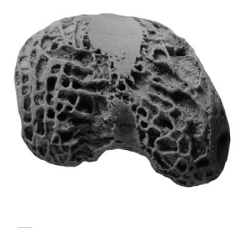

$P$

Figure 5. Fossils of the palaeognathous Lithornithidae from the middle Thanetian of Templeuve (France). A, B, right coracoid lacking extremitas omalis (IRSNB Av 218) in ventral (A) and dorsal (B) view. C, D, proximal end of right humerus (IRSNB Av 219) in cranial (C) and caudal (D) view. E, F, distal end of right humerus (IRSNB Av 219), which stems from the same individual as the proximal humerus, in cranial (E) and caudal (F) view. G, tentatively referred right radius lacking distal tip (IRSNB Av 223). H, I, partial left carpometacarpus in two pieces (IRSNB Av 220) in ventral (H) and dorsal (I) view. J, K, proximal end of left carpometacarpus (IRSNB Av 221) in ventral (J) and dorsal (K) view. L, M, distal portion of left os metacarpale majus of carpometacarpus (IRSNB Av 224) ventral (L) and dorsal (M) view. N-P, distal end of left tibiotarsus (IRSNB Av 222) in cranial (N), caudal (O), and distal (P) view. Abbreviations: blg, broken bulge on cranial surface of proximal humerus; cdd, condylus dorsalis; ext, sulcus extensorius; fmb, fossa musculi brachialis; fns, foramen nervi supracoracoidei; fos, fossa caudal of processus pisiformis; fpt, fossa pneumotricipitalis; inf, fossa infratrochlearis; mid, sulcus for tendon of musculus interosseus dorsalis; miv, sulcus for tendon of musculus interosseus ventralis; pla, processus lateralis; rdg, ridge delimiting facies interna of crista articularis sternalis; std, sulcus tendinosus; stv, sulcus transversus; tbr, tuberculum bicipitale radii; tsv, tuberculum supracondylare ventrale. All specimens were coated with ammonium chloride. Scale bar equals $5 \mathrm{~mm}$. 2011)

Aves indet., species B (cf. Colymbiculus Mayr \& Zvonok,

(Figs 6D-F)

Referred specimen. IRSNB Av 226: left tibiotarsus lacking proximal end (collected by Guy Van Den Eeckhaut).

Measurements. Length as preserved, $39.8 \mathrm{~mm}$; distal width, $6.3 \mathrm{~mm}$.

Remarks. In size and morphology, the fossil resembles the tibiotarsus of the stem group gaviiform Colymbiculus udovichenkoi from the middle Eocene of the Ukraine (Fig. 6G; Mayr \& Zvonok, 2011). As in the latter species, the proximal portion of the shaft is craniocaudally flattened, with convex cranial and caudal surfaces. Unlike in Colymbiculus, however, the shaft of IRSNB Av 226 is curved and the proximal and distal ends are medially inflected. The condyles of IRSNB Av 226 are abraded and the trochlea cartilaginis tibialis is broken. However, 

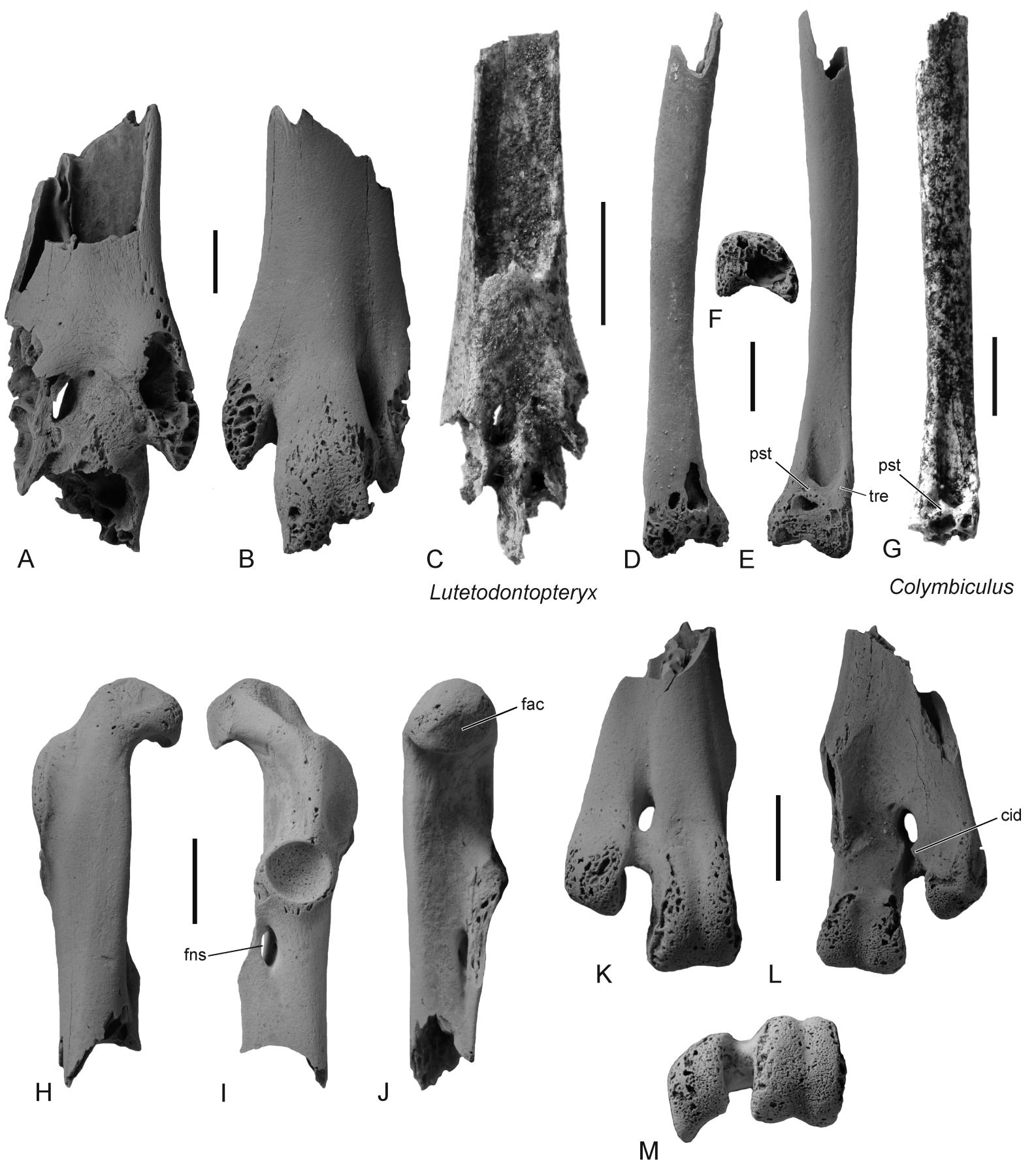

Figure 6. Further avian remains from the middle Thanetian of Templeuve (France), as well as specimens of Lutetodontopteryx and Colymbiculus from the middle Eocene of the Ukraine. A, B, distal end of a left tarsometatarsus of a pelagornithid (IRSNB Av 225) in plantar (A) and dorsal (B) view. C, distal end of the left tarsometatarsus (plantar view) of Lutetodontopteryx tethyensis from the middle Eocene of the Ukraine in a similar state of preservation (SMF Av 544). D-F, Aves indet., species B (cf. Colymbiculus), left tibiotarsus lacking the proximal end (IRSNB Av 226), in caudal (D), cranial (E), and distal (F) view. G, left tibiotarsus of Colymbiculus udovichenkoi from the middle Eocene of the Ukraine in cranial view (SMF Av 551). H-J, Aves indet., species C, extremitas omalis of right coracoid (IRSNB Av 227) in ventral (H), dorsal (I), and medial (J) view. K-M, Aves indet., species C, distal end of right tarsometatarsus lacking trochlea metatarsi II (IRSNB Av 228) in dorsal (K), plantar (L), and distal (M) view. Abbreviations: cid, plantarly open canalis interosseus distalis; fac, facies articularis clavicularis; fns, foramen nervi supracoracoidei; pst, pons supratendineus; tre, tuberositas retinaculi extensori. All fossils except for those in $\mathrm{C}$ and $\mathrm{G}$ were coated with ammonium chloride. Scale bars equal $5 \mathrm{~mm}$.

it can still be discerned that the condyles were widely spaced and that the condylus lateralis was larger than the condylus medialis. The very wide sulcus extensorius is shallow and centrally positioned, but the distal opening of the canalis extensorius is located more towards the medial side of the bone than in Colymbiculus. The pons supratendineus is proximodistally wide and laterally bordered by an elongated embossment (presumably the lateral part of the tuberositas retinaculi extensori). The pons supratendineus of the fossil from Templeuve appears wider than that of Colymbiculus, which may, however, be due to the fact that this osseous bridge is damaged in the only known tibiotarsus of the Ukrainian taxon.

\section{Aves indet., species $\mathrm{C}$}

(Figs 6H-M)

Referred specimen. IRSNB Av 227: extremitas omalis of right coracoid (collected by Gino Mariën).

Tentatively referred specimen. IRSNB Av 228: distal end of right tarsometatarsus lacking trochlea metatarsi II (collected by Gino Mariën). 
Measurements. Coracoid, length as preserved, $24.3 \mathrm{~mm}$. Tarsometatarsus, length as preserved, $21.0 \mathrm{~mm}$; width of trochlea metatarsi III, $5.5 \mathrm{~mm}$.

Remarks. In size, the fragmentary tarsometatarsus matches the coracoid IRSNB Av 227 and both fossils may be from the same species. Even though the specimens correspond in size to the above-described lithornithid bones from Templeuve, they differ in their morphology from the coracoid and tarsometatarsus of the Lithornithidae.

The processus acrocoracoideus of the coracoid (Figs $6 \mathrm{H}-\mathrm{J}$ ) is proportionally longer than in lithornithids and unlike in the latter it has a hook-like shape, with the facies articularis clavicularis forming a lip that overhangs the sulcus supracoracoideus. The cotyla scapularis is cup-like and has a more circular outline than in lithornithids. The processus procoracoideus is broken. A large foramen nervi supracoracoidei is present. The coracoid shows an overall resemblance to the coracoid of the anseriform Presbyornithidae, from which it is, however, distinguished in the hook-shaped processus acrocoracoideus and in the absence of a fossa in the dorsal portion of the sulcus supracoracoideus (compare Figs 6I, J with Kurochkin \& Dyke, 2010, fig. 7). With regard to the circular cotyla scapularis and the shape of the processus acrocoracoideus, the specimen from Templeuve is more similar to coracoids of undetermined ornithurines from the latest Cretaceous of North America (Longrich et al., 2011, figs 3A, C, $\mathrm{D}, \mathrm{J})$. These resemblances may reflect a plesiomorphic coracoid morphology for neognathous birds, and a similar shape occurs in some extant Anseriformes, Charadriiformes, and Gruiformes.

The tarsometatarsus (Figs 6K-M) exhibits a large foramen vasculare distale and the canalis interosseus distalis is plantarly open. The trochlea metatarsi II is broken, but judging from the shape and position of the breakage, it appears to have been shorter than the trochlea metatarsi IV and was at least somewhat more plantarly deflected. The overall morphology of the tarsometatarsus suggests that it is from a terrestrial bird, but the plantar articular surface of the trochlea metatarsi III is less asymmetrical than that of the Lithornithidae. With regard to the plantarly open canalis interosseus distalis, the fossil resembles a similar-sized fragmentary tarsometatarsus of uncertain affinities from the early Eocene of Egem (Belgium), which was figured by Mayr \& Smith (2019, fig. 11C). However, the incomplete preservation of the latter fossil, which lacks the trochleae metatarsorum II and IV and has a damaged trochlea metatarsi III, impedes meaningful further comparisons.

\subsection{Specimens from Rivecourt-Petit Pâtis (France, latest Thanetian, $56.5 \mathrm{Ma}$ )}

Ralloidea Vigors, 1825

Gen. et sp. indet.

(Figs 7A, B)

Referred specimen. MAV Riv. PP 139: right coracoid lacking extremitas sternalis.

Measurements. Length as preserved, $17.1 \mathrm{~mm}$.

Remarks. The fossil closely corresponds with the coracoid of the Ralloidea (rails, sungrebes, and allies). As in other members of this clade, there is a well-developed crista procoracoidei along the medial margin of the shaft of the bone, the shaft is pierced by a foramen nervi supracoracoidei, and the facies articularis humeralis is laterally prominent, short in sterno-omal direction, and forms a markedly convex bulge. The processus acrocoracoideus is narrow in sterno-omal direction; its tip and that of the processus procoracoideus are broken. Overall, MAV Riv. PP 139 most closely resembles the coracoid of the Messelornithidae (Fig. 7C) and that of some extant Rallidae (Fig. 7D), but an unambiguous assignment to any ralloid subclade is not possible. The fossil differs from Walbeckornis from the Selandian of Walbeck (Mayr, 2007) in that the crista procoracoidei is better developed and in that the facies articularis humeralis is shorter and more strongly laterally bulging.

?Leptosomiformes Sharpe, 1891

Gen. et sp. indet. (cf. Plesiocathartes Gaillard, 1908)

(Figs 7E-G)
Referred specimen. MAV Riv. PP 138: distal end of left tarsometatarsus lacking trochlea metatarsi IV.

Measurements. Length as preserved, $19.3 \mathrm{~mm}$; width of trochlea metatarsi III, $3.2 \mathrm{~mm}$; estimated distal width, $9.5-10 \mathrm{~mm}$.

Remarks. This specimen is characterized by the shape of the trochlea metatarsi II, which is hardly plantarly deflected, lacks a plantarly directed flange, and reaches almost as far distally as the trochlea metatarsi III. The fossa metatarsi I is well developed, and there is a well-delimited sulcus extensorius proximal of the foramen vasculare distale. With regard to these features, the fossil most closely resembles the tarsometatarsus of the Eocene Plesiocathartes (Figs 7H, I). This taxon is a stem group representative of the Leptosomiformes and is known from various early Eocene localities in Europe (London Clay, Mayr, 2002b; Egem in Belgium, Mayr \& Smith, 2019) and North America (Green River Formation, Weidig, 2006), and the middle Eocene of the German locality Geiseltal (Mayr, 2002c). A Plesiocatharteslike fossil was also reported from the early Eocene Vastan lignite mine in India (Mayr et al., 2010). Extant Leptosomiformes, by contrast, include only a single species that occurs on Madagascar and the Comoros.

\section{Aves indet., species D}

(Figs 7K-M)

Referred specimen. MAV Riv. PP 870: distal portion of left tarsometatarsus lacking trochlea metatarsi III.

Measurements. Length as preserved, $37.2 \mathrm{~mm}$; distal width as preserved, $12.1 \mathrm{~mm}$.

Remarks. The proportions of this bone fragment suggest that it stems from a terrestrial bird with a fairly long tarsometatarsus, which probably had a length of more than $70 \mathrm{~mm}$. Because all trochleae are damaged or broken, a reliable identification of the bone is not possible. The foramen vasculare distale is of average size and situated at the end of a marked sulcus extensorius. A canalis interosseus distalis is present. The fossa metatarsi I is large and distinct, which indicates the presence of a welldeveloped hallux. A low ridge runs along the midsection of the plantar surface of the shaft of the bone.

In size and morphology, the fossil resembles the tarsometatarsus of the taxon Gradiornis from Walbeck (Fig. $7 \mathrm{~J}$ ), which was likened to the Cariamiformes by Mayr (2007). However, there are some differences, with the trochlea metatarsi III of MAV Riv. PP 870 being less deep in a dorso-plantar direction and the bone section between the distal end of the foramen vasculare distale and the incisura intertrochlearis lateralis being distinctly shorter in MAV Riv. PP 870 . In overall morphology, MAV Riv. PP 870 is also similar to the tarsometatarsus of the cariamiform Idiornithidae (Mourer-Chauviré, 1983), but the foramen vascular distale is larger in the fossil from Rivecourt and the plantar flange formed by the trochlea metatarsi II is smaller.

\section{Discussion}

\subsection{General characteristics of Paleocene avifaunas}

In the Cretaceous, ecological niches for arboreal birds were occupied by the archaic Enantiornithes, whereas arboreal crown group birds (Neornithes) were absent in Mesozoic ecosystems (Mayr, 2014). The end-Cretaceous mass extinction event terminated the existence of enantiornithines and other avian taxa outside the crown group, and only neornithine lineages transitioned the $\mathrm{K} / \mathrm{Pg}$ boundary. It was first hypothesized by Mayr $(2017 \mathrm{a}, 92 \mathrm{f}$.) that those neornithine birds, which crossed the $\mathrm{K} / \mathrm{Pg}$ boundary, had a terrestrial or aquatic way of life and that a "selective extinction of avian lineages at the K/Pg boundary could have been triggered by profound vegetation changes, such as large-scale deforestations (...). This would not only have led to the extinction of arboreal enantiornithines, but, through changes of atmospheric carbon dioxide levels and accompanied oceanic acidification (...), could have also affected the food chains of marine ecosystems. Predominantly terrestrial birds that did not live in forested environments, by contrast, may have been less affected". Mayr (2017a, 204f.) further noted that "no small arboreal neornithine birds are known from Cretaceous or 


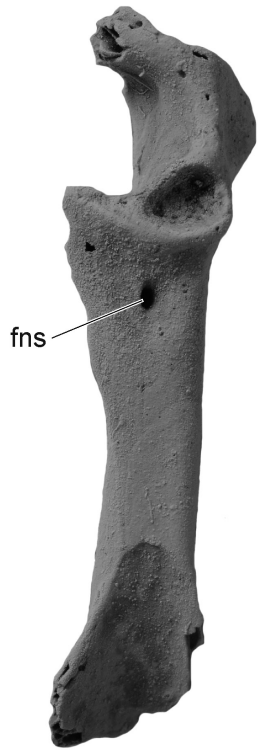

A

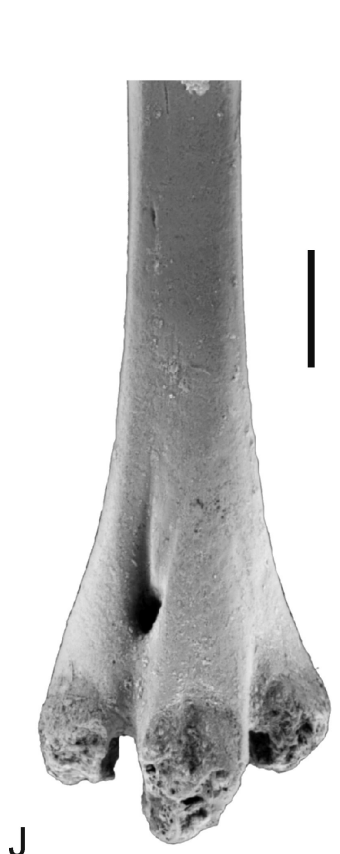

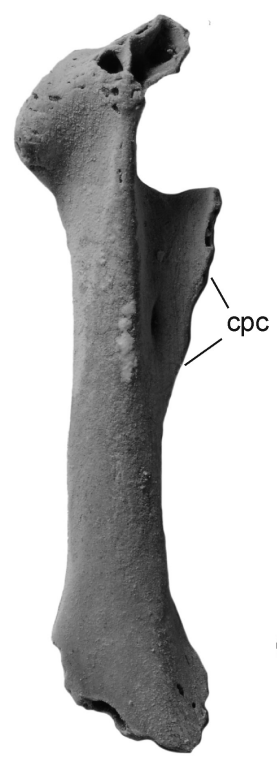

B

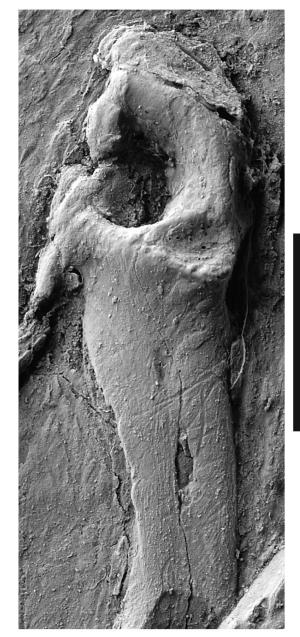

C Messelornis

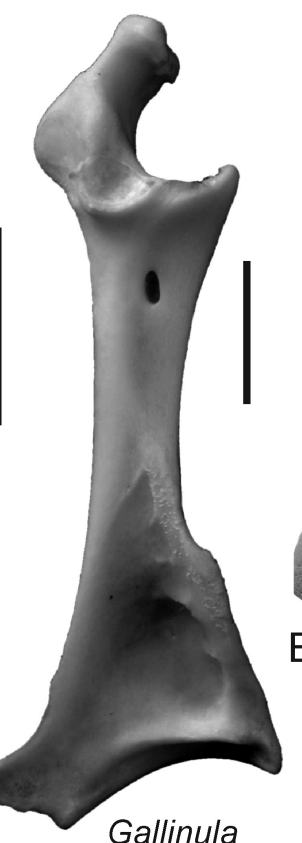

Gallinula

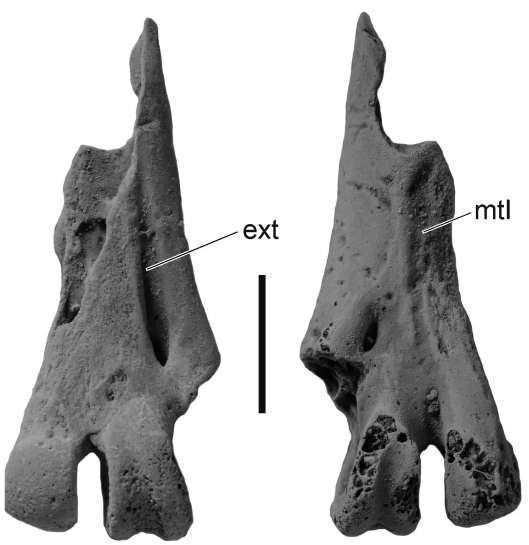

F

G

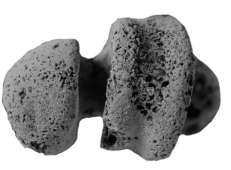

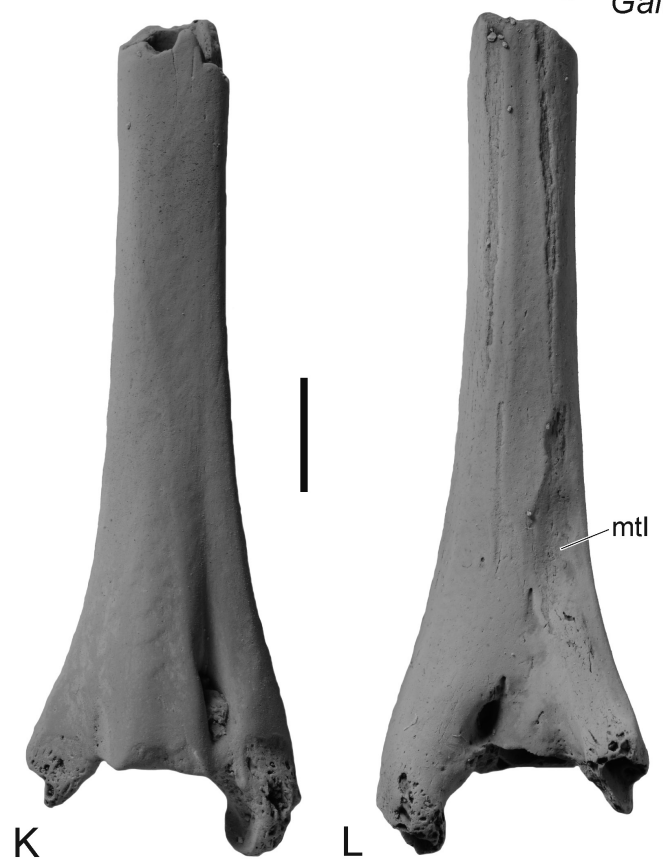

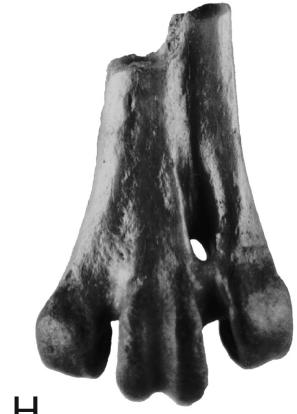

$\mathrm{H}$

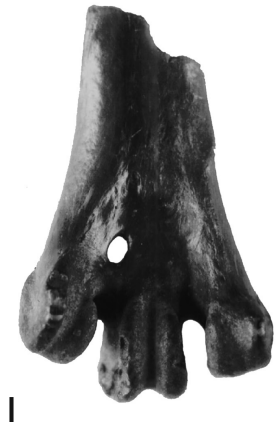

Plesiocathartes (London Clay)

Gradiornis

Figure 7. Specimens from the late Thanetian of Rivecourt-Petit Pâtis (France) in comparison to selected fossil and extant taxa. A, B, Ralloidea, incomplete right coracoid from Rivecourt (MAV Riv. PP 139) in dorsal (A) and ventral (B) view. C, omal portion of right coracoid of Messelornis cristata (Messelornithidae) from the early Eocene of Messel, Germany (SMF-ME 2614a) in dorsal view. D, Left coracoid (dorsal view) of the extant Gallinula chloropus (Rallidae). E-G, ?Leptosomiformes (cf. Plesiocathartes), distal end of left tarsometatarsus from Rivecourt lacking trochlea metatarsi IV (MAV Riv. PP 138) in dorsal (E), plantar (F), and distal (G) view. H, I, distal end of left tarsometatarsus of an undescribed Plesiocathartes species from the London Clay in England (NHMUK A 6178) in dorsal (H) and plantar (I) view. J, right tarsometatarsus from the Selandian of Walbeck, Germany that was assigned to Gradiornis walbeckensis (IGWuG WAL359.2007). K-M, Aves indet., species D, distal portion of left tarsometatarsus from Rivecourt lacking trochlea metatarsi III (MAV Riv. PP 870) in dorsal (K), plantar (L), and distal (M) view. Abbreviations: cpc, crista procoracoidei; ext, sulcus extensorius; fns, foramen nervi supracoracoidei; mtI, fossa metatarsi I. All specimens except for those in D, H, and I were coated with ammonium chloride. Scale bars equal $5 \mathrm{~mm}$.

even early Paleocene deposits. In the early Eocene, by contrast, stem group representatives of most extant arboreal lineages were already present. It therefore seems well possible that a causal correlation existed between the extinction of the arboreal Enantiornithes at the end of the Mesozoic and the radiation of arboreal Neornithines thereafter." Virtually the same conclusions were subsequently reached by Field et al. (2018), who seem to have overlooked the above publication and did not comment on the extinction of the non-arboreal Ichthyornithiformes and Hesperornithiformes at the $\mathrm{K} / \mathrm{Pg}$ boundary.

The early evolution of Telluraves, the arboreal landbird clade, remains poorly known owing to the scarce Paleocene fossil record. The earliest representative of Telluraves stems from the late Danian (late Torrejonian North American Land Mammal Age; 62.5 Ma) of New Mexico, USA (Ksepka et al., 2017). The earliest unambiguous record of an arboreal bird from the European Paleocene is a skeleton from Menat (60-61 Ma), which is of uncertain phylogenetic affinities within Telluraves (Mayr et al., 2019a). The only putative representative of the arboreal landbird clade (Telluraves) in our sample is the fragmentary tarsometatarsus from Rivecourt, which we tentatively assign to the Leptosomiformes. With an estimated age of $56.5 \mathrm{Ma}$, this fossil is several million years younger than the aforementioned records from New Mexico and Menat and approaches in age the well-known and diversified early Eocene arboreal avifaunas of the Danish Fur Formation and the British London Clay. We note the 
possibility that the very small tarsometatarsus from Maret (Aves indet., species A) may represent an earlier record of Telluraves, but the specimen is much too fragmentary for a reliable identification. As a consequence, there exists no unambiguous evidence for the presence of arboreal representatives of Telluraves in Europe before the late Paleocene.

In addition to the scarcity of telluravian taxa, terrestrial Paleocene avifaunas also feature another characteristic that is likely to have been related to the end-Cretaceous mass extinction: the occurrence of large flightless birds. Mayr (2009, 215) hypothesized that the absence of large terrestrial predators after the $\mathrm{K} / \mathrm{Pg}$ extinction event enabled the evolution of flightlessness in a number of avian lineages, and this hypothesis was further detailed by Mayr (2011, 2017a). Flight loss was furthermore favored by the habitat preferences of the birds surviving the K/ $\mathrm{Pg}$ extinction, which had a terrestrial or aquatic way of life, and it is probably no coincidence that the earliest fossil records of flightless Sphenisciformes and Palaeognathae as well the earliest records of the South American Phorusrhacidae stem from the mid-Paleocene (Mayr, 2017a). In Europe, gastornithids are known from several Paleocene localities in France, Belgium, Germany, and England (Buffetaut, 1997; Mayr, 2009; Buffetaut \& Angst, 2014) and prior to our study the oldest fossil record of these birds was a coracoid from Walbeck.

The exact stratigraphic correlation between Maret and Walbeck is unknown and it therefore remains elusive whether the specimen from Maret or that from Walbeck is the earliest record of the Gastornithidae. In any case, however, the fragmentary femur from Maret is the earliest well-dated record of gastornithids and documents that these birds were present in Europe about 61 million years ago. As detailed by Mayr (2009), a small size is likely to be plesiomorphic within Gastornithidae and both the size of the known species as well as the dates of their first occurrence suggest a European origin of gastornithids (Buffetaut, 1997; Mayr, 2009). Gastornithids first occur in North America towards the Paleocene/Eocene boundary and the absence of both gastornithids and the flightless palaeognathous Remiornithidae in the Paleocene of North America may be due to the fact that North America featured greater numbers of larger carnivorous mammals during the Paleocene (Oxyaenidae and Mesonychidae occur at least since the middle Paleocene) than did Europe (no Oxyaenidae before the earliest Eocene of Dormaal, Belgium; oldest Mesonychidae from the late Paleocene of the Mont-deBerru area, France). Initial flight loss of the gastornithid stem species could only have taken place in a predator-free environment and these birds probably did not reach North America before a very large body size made them less prone to predation.

\subsection{Comparisons with other Paleocene localities from Europe and North America}

The localities examined in the present study differ in their paleoenvironments, and whereas Maret and Templeuve expose marine strata, the fossiliferous sediments of Rivecourt are of fluviatile origin. However, most of the identifiable remains belong to birds that lived on land, and only the pelagornithid tarsometatarsus from Templeuve stems from a marine bird (if affinities to the gaviiform taxon Colymbiculus are confirmed in future studies, the species represented by the small tibiotarsus from Templeuve may be another seabird).

Early Eocene landbird faunas of North America and Europe are very similar (Mayr, 2009, 2017b), but it is unknown when exactly the faunal exchange between these continents commenced. Avifaunal correlations between mid and late Paleocene localities of Europe and North America are documented by the occurrence of the palaeognathous Lithornithidae on both continents. In North America, lithornithids first occur in the Selandian (Tiffanian North American Land Mammal Age), with the oldest record being from the early Tiffanian ( $\sim 61 \mathrm{Ma}$ ) of Montana (Houde, 1988; Stidham et al., 2014). Our recognition of lithornithids in two Paleocene European localities (Maret and Templeuve) is significant, because the previous identification of lithornithids in Walbeck is only tentative (Mayr, 2007) and the specimen, an incomplete coracoid that was assigned to the taxon Fissuravis, differs from typical lithornithids in several features. The fossils from Maret constitute further evidence for the presence of lithornithids in the mid-Paleocene of Europe and, if correctly identified, would be of comparable age to the earliest North American lithornithid remains. The unambiguously identified specimens from Templeuve also clearly predate the next oldest European records of the Lithornithidae, which are a distal humerus from the latest Paleocene/earliest Eocene Ølst Formation in Denmark (Bourdon \& Lindow, 2015) and partial skeletons from the Ypresian of the Danish Fur Formation (Kristoffersen, 1999; Bourdon \& Lindow, 2015) and the British London Clay (Houde, 1988). Whereas the previously known fossil record of lithornithids suggested a dispersal of these birds from North America into Europe, a straightforward interpretation of the fossil record is impeded by the new finds and the center of origin of lithornithids currently remains elusive.

The putative ralloid from Maret rivals with Walbeckornis from Walbeck (Mayr, 2007) and Songzia-like birds from Menat (Mayr et al., 2019a) as the potentially oldest fossil record of the Ralloidea. A definitive record of the Ralloidea exists from Rivecourt (this study) and remains of the Messelornithidae were described from the Mont-de-Berru area in France (MourerChauviré, 1995). Accordingly, gruiform birds, and representatives of the Ralloidea in particular, have a long evolutionary history in Europe, whereas there exists no Paleocene record of the Ralloidea from North America.

A notable absence among the fossil assemblages studied by us concerns the strigiform taxon Berruornis, which was reported from the Mont-de-Berru area and Walbeck (Mourer-Chauviré, 1994; Mayr, 2002a, 2007). Strigiform birds are also known from the Paleocene of North America (Rich \& Bohaska, 1981) and their absence in all three localities considered in the present study is likely to be an artefact of the limited fossil record.

Despite the small sample size, however, our study documents avian taxa that have not yet been reported from Paleocene deposits in Europe or anywhere else. Such is true for the fragmentary tarsometatarsus from Rivecourt, which we tentatively assign to the Leptosomiformes. Irrespective of its exact phylogenetic affinities, the tibiotarsus from Templeuve, which - based on a resemblance to the tibiotarsus of the middle Eocene taxon Colymbiculus - is tentatively assigned to the Gaviiformes, likewise represents a taxon that has not yet been reported from the Paleocene of Europe.

As yet, only the palaeognathous Lithornithidae are known from the Paleocene of both Europe and North America, and there appear to have existed significant avifaunal differences in the earliest Cenozoic of the two Northern Hemispheric continents. The anseriform Presbyornithidae, for example, have been reported from several mid-Paleocene (Tiffanian) localities in North America (Olson, 1994; Benson, 1999) and from the late Paleocene of Mongolia (Kurochkin \& Dyke, 2010), but unambiguous records of these birds are as yet altogether unknown from Europe. Likewise unknown from the European Paleocene is the enigmatic taxon Calcardea from the Clarkforkian of Wyoming, which has recently been shown similar to the parrotlike Indian taxon Vastanavis (Mayr et al., 2019b). Remains of the Pelagornithidae, on the other hand, are well known from other Paleocene sites in England (Harrison, 1985) and Morocco (Bourdon et al., 2010), but pelagornithids have not been reported from any Paleocene site in the New World (Mayr, 2009, 2017a). The current fossil record therefore suggests that the very similar early Eocene avifaunas of Europe and North America are the result of early Cenozoic dispersal events. As such, the avian fossil record corresponds with mammalian faunas, which before the dispersal events towards the Paleocene-Eocene Thermal Maximum (e.g. Smith et al., 2006; Beard, 2008) also showed distinct differences in the mid-Paleocene of Europe and North America.

\section{Acknowledgements}

We are indebted to the collectors Pieter De Schutter, Philippe Garot, Gino Mariën, and Guy Van Den Eeckhaut for donating fossils to IRSNB - without their efforts and cooperation, this study would not have been possible. We furthermore thank Sven Tränkner (SMF) and Nathan Vallée Gillette (IRSNB) for taking the photographs, and Annelise Folie (IRSNB) for her assistance 
in inventorying the fossils. We thank the reviewers, Peter Houde (New Mexico State University) and Zbigniew Bocheński (Polish Academy of Sciences, Kraków), as well as the Associate Editor Etienne Steurbaut for comments that improved the manuscript.

\section{References}

Anthonissen, D.E. \& Ogg, G.G., 2012. Cenozoic and Cretaceous biochronology of planktonic foraminifera and calcareous nannofossils. In Gradstein, F.M., Ogg, J.G., Schmitz, M. \& Ogg, G. (eds), The Geologic Time Scale. Elsevier, Amsterdam, Appendix 3, 1083-1127. https://doi.org/10.1016/B978-0-444-59425-9.15003-6

Aubry, M.-P., Thiry, M., Dupuis, C. \& Berggren, W.A., 2005. The Sparnacian deposits of the Paris Basin: a lithostratigraphic classification. Stratigraphy, 2, 65-100.

Baumel, J.J. \& Witmer, L.M., 1993. Osteologia. In Baumel, J.J., King, A.S., Breazile, J.E., Evans, H.E. \& Vanden Berge, J.C. (eds), Handbook of Avian Anatomy: Nomina Anatomica Avium. Publications of the Nuttall Ornithological Club, 23, 45-132.

Beard, K.C., 2008. The oldest North American primate and mammalian biogeography during the Paleocene-Eocene Thermal Maximum. Proceedings of the National Academy of Sciences of the United States of America, 105, 3815-3818. https://doi.org/10.1073/ pnas.0710180105

Benson, R.D., 1999. Presbyornis isoni and other late Paleocene birds from North Dakota. In Olson, S.L. (ed.), Avian Paleontology at the Close of the 20th Century: Proceedings of the 4th International Meeting of the Society of Avian Paleontology and Evolution, Washington, D.C., 4-7 June 1996. Smithsonian Contributions to Paleobiology, 89, 253-259.

Berggren, W.A. \& Aubry, M.-P., 1996. A late Paleocene-early Eocene NW European and North Sea magnetobiochronological correlation network. Geological Society, London, Special Publications, 101, 309-352. https://doi.org/10.1144/GSL.SP.1996.101.01.17

Bourdon, E. \& Lindow, B., 2015. A redescription of Lithornis vulturinus (Aves, Palaeognathae) from the Early Eocene Fur Formation of Denmark. Zootaxa, 4032, 493-514. http://dx.doi.org/10.11646/ zootaxa.4032.5.2

Bourdon, E., Amaghzaz, M. \& Bouya, B., 2010. Pseudotoothed birds (Aves, Odontopterygiformes) from the early Tertiary of Morocco. American Museum Novitates, 3704, 1-71. https://doi. org/10.1206/3704.2

Buffetaut, E., 1997. New remains of the giant bird Gastornis from the Upper Palaeocene of the eastern Paris Basin and the relationships between Gastornis and Diatryma. Neues Jahrbuch für Geologie und Paläontologie, Monatshefte, 3, 179-190.

Buffetaut, E. \& Angst, D., 2014. Stratigraphic distribution of large flightless birds in the Palaeogene of Europe and its palaeobiological and palaeogeographical implications. Earth-Science Reviews, 138, 394-408. https://doi.org/10.1016/j.earscirev.2014.07.001

Cheneval J., 1996. Tertiary avian localities of Belgium. In Mlíkovský, J., (ed.), Tertiary Avian Localities of Europe. Acta Universitatis Carolinae, Geologica, 39, 535-540.

Dames, W., 1890. Ueber Vogelreste aus dem Saltholmskalk von Limhamn bei Malmö. Bihang till Kungliga Svenska Vetenskapsakademiens Handlingar, 16, 3-11.

De Bast, E., Steurbaut, E. \& Smith, T., 2013. New mammals from the marine Selandian of Maret, Belgium, and their implications for the age of the Paleocene continental deposits of Walbeck, Germany. Geologica Belgica, 16, 236-244.

Dollo, L., 1883. Note sur la présence du Gastornis Edwardsii, Lemoine, dans l'assise inférieure de l'étage Landénien à Mesvin, près Mons. Bulletin du Musée royal d'Histoire naturelle de Belgique, 2, 297 305.

Field, D.J., Bercovici, A., Berv, J.S., Dunn, R., Fastovsky, D.E., Lyson, T.R., Vajda, V. \& Gauthier, J., 2018. Early evolution of modern birds structured by global forest collapse at the end-Cretaceous mass extinction. Current Biology, 28, 1825-1831. https://doi. org/10.1016/j.cub.2018.04.062

Fischer, K., 1978. Neue Reste des Riesenlaufvogels Diatryma aus dem Eozän des Geiseltals bei Halle (DDR). Mitteilungen aus dem Zoologischen Museum in Berlin, 54, Supplement: Annalen für Ornithologie, 2, 133-144.

Harrison, C.J.O., 1985. A bony-toothed bird (Odontopterygiformes) from the Palaeocene of England. Tertiary Research, 7, 23-25.

Hou, L.-H., 1994. [A new Paleocene bird from Anhui, China]. Vertebrata PalAsiatica, 32, 60-65. [In Chinese].

Houde, P., 1988. Paleognathous birds from the early Tertiary of the Northern Hemisphere. Publications of the Nuttall Ornithological Club, 22, 1-148.
Kristoffersen, A.V., 1999. Lithornithid birds (Aves, Palaeognathae) from the lower Palaeogene of Denmark. Geologie en Mijnbouw, 78, 375381. https://doi.org/10.1023/A:1003824021505

Ksepka, D.T., Stidham, T.A. \& Williamson, T.E., 2017. Early Paleocene landbird supports rapid phylogenetic and morphological diversification of crown birds after the K-Pg mass extinction. Proceedings of the National Academy of Sciences of the United States of America, 114, 8047-8052. https://doi.org/10.1073/ pnas. 1700188114

Kurochkin, E.N. \& Dyke, G.J., 2010. A large collection of Presbyornis (Aves, Anseriformes, Presbyornithidae) from the late Paleocene and early Eocene of Mongolia. Geological Journal, 45, 375-387. https:// doi.org/10.1002/gj.1177

Lemoine, V., 1878. Recherches sur les oiseaux fossiles des terrains tertiaires inférieurs des environs de Reims. F. Keller, Reims, 69 p.

Lemoine, V., 1881. Recherches sur les oiseaux fossiles des terrains tertiaires inférieurs des environs de Reims, deuxième partie. MatotBraine, Reims, 95 p.

Longrich, N.R., Tokaryk, T. \& Field, D.J., 2011. Mass extinction of birds at the Cretaceous-Paleogene (K-Pg) boundary. Proceedings of the National Academy of Sciences of the United States of America, 108, 15253-15257. https://doi.org/10.1073/pnas.1110395108

Martin, L.D., 1992. The status of the Late Paleocene birds Gastornis and Remiornis. In Campbell, K.E. (ed.), Papers in Avian Paleontology honoring Pierce Brodkorb. Natural History Museum of Los Angeles County, Science Series, 36, 97-108.

Mayr, G., 2002a. An owl from the Paleocene of Walbeck, Germany. Mitteilungen aus dem Museum für Naturkunde in Berlin, Geowissenschaftliche Reihe, 5, 283-288. https://doi.org/10.1002/ mmng.20020050117

Mayr, G., 2002b. A new species of Plesiocathartes (Aves: ?Leptosomidae) from the Middle Eocene of Messel, Germany. PaleoBios, 22, 10-20.

Mayr, G., 2002c. Avian remains from the Middle Eocene of the Geiseltal (Sachsen-Anhalt, Germany). In Zhou, Z. \& Zhang, F. (eds), Proceedings of the 5th Symposium of the Society of Avian Paleontology and Evolution, Beijing, 1-4 June 2000. Science Press, Beijing, 77-96.

Mayr, G., 2007. The birds from the Paleocene fissure filling of Walbeck (Germany). Journal of Vertebrate Paleontology, 27, 394-408. https:// doi.org/10.1671/0272-4634(2007)27[394:TBFTPF]2.0.CO;2

Mayr, G., 2009. Paleogene Fossil Birds. Springer, Heidelberg, 262 p. https://doi.org/10.1007/978-3-540-89628-9

Mayr, G., 2011. Two-phase extinction of "Southern Hemispheric" birds in the Cenozoic of Europe and the origin of the Neotropic avifauna. Palaeobiodiversity and Palaeoenvironments, 91, 325-333. https:// doi.org/10.1007/s12549-011-0062-4

Mayr, G., 2014. The origins of crown group birds: molecules and fossils. Palaeontology, 57, 231-242. https://doi.org/10.1111/pala.12103

Mayr, G., 2017a. Avian Evolution: The Fossil Record of Birds and its Paleobiological Significance. Wiley-Blackwell, Chichester, 293 p.

Mayr, G., 2017b. The early Eocene birds of the Messel fossil site: a 48 million-year-old bird community adds a temporal perspective to the evolution of tropical avifaunas. Biological Reviews, 92, 1174-1188. https://doi.org/10.1111/brv.12274

Mayr, G. \& Smith, T., 2019. A diverse bird assemblage from the Ypresian of Belgium furthers knowledge of early Eocene avifaunas of the North Sea Basin. Neues Jahrbuch für Geologie und Paläontologie, Abhandlungen, 291, 253-281. https://doi.org/10.1127/ njgpa/2019/0801

Mayr, G. \& Zvonok, E., 2011. Middle Eocene Pelagornithidae and Gaviiformes (Aves) from the Ukrainian Paratethys. Palaeontology, 54, 1347-1359. https://doi.org/10.1111/j.1475-4983.2011.01109.x

Mayr, G., Rana, R.S., Rose, K.D., Sahni, A., Kumar, K., Singh, L. \& Smith, T., 2010. Quercypsitta-like birds from the early Eocene of India (Aves, ?Psittaciformes). Journal of Vertebrate Paleontology, 30, 467-478. https://doi.org/10.1080/02724631003617357

Mayr, G., Hervet, S. \& Buffetaut, E., 2019a. On the diverse and widely ignored Paleocene avifauna of Menat (Puy-de-Dôme, France): new taxonomic records and unusual soft tissue preservation. Geological Magazine, 156, 572-584. https://doi.org/10.1017/ S0016756818000080

Mayr, G., Gingerich, P.D. \& Smith, T., 2019b. Calcardea junnei Gingerich, 1987 from the late Paleocene of North America is not a heron, but resembles the early Eocene Indian taxon Vastanavis Mayr et al., 2007. Journal of Paleontology, 93, 359-367. https://doi. org/10.1017/jpa.2018.85

Misonne, X., 1958. Faune du Tertiaire et du Pléistocène inférieur de Belgique (oiseaux et mammifères). Bulletin de l'Institut royal des Sciences naturelles de Belgique, 34, 1-36.

Moreau, F. \& Mathis, S., 2000. Les élasmobranches du Thanétien (Paléocène) du Nord de la France, des carrières de Templeuve et de Leforest. Cossmanniana, 7, 1-18. 
Mourer-Chauviré, C., 1983. Les Gruiformes (Aves) des Phosphorites du Quercy (France). 1. Sous-ordre Cariamae (Cariamidae et Phorusrhacidae). Systématique et biostratigraphie. Palaeovertebrata, $13,83-143$.

Mourer-Chauviré, C., 1994. A large owl from the Palaeocene of France. Palaeontology, 37, 339-348.

Mourer-Chauviré, C., 1995. The Messelornithidae (Aves: Gruiformes) from the Paleogene of France. Courier Forschungsinstitut Senckenberg, 181, 95-105.

Mourer-Chauviré, C. \& Bourdon, E., 2016. The Gastornis (Aves, Gastornithidae) from the Late Paleocene of Louvois (Marne, France). Swiss Journal of Palaeontology, 135, 327-341. https://doi. org/10.1007/s13358-015-0097-7

Nesbitt, S.J. \& Clarke, J.A., 2016. The anatomy and taxonomy of the exquisitely preserved Green River Formation (early Eocene) lithornithids (Aves) and the relationships of Lithornithidae. Bulletin of the American Museum of Natural History, 406, 1-91. https://doi. org/10.1206/0003-0090-406.1.1

Olson, S.L., 1994. A giant Presbyornis (Aves: Anseriformes) and other birds from the Paleocene Aquia Formation of Maryland and Virginia. Proceedings of the Biological Society of Washington, 107, 429-435.

Rich, P.V. \& Bohaska, D.J., 1981. The Ogygoptyngidae, a new family of owls from the Paleocene of North America. Alcheringa, 5, 95-102. https://doi.org/10.1080/03115518108565424

Smith, T. \& Smith, R., 2003. Terrestrial mammals as biostratigraphic indicators in Upper Paleocene-Lower Eocene marine deposits of the southern North Sea Basin. Geological Society of America, Special Papers, 369, 513-520. https://doi.org/10.1130/0-8137-2369-8.513

Smith, T., Rose, K.D. \& Gingerich, P.D., 2006. Rapid Asia-Europe-North America geographic dispersal of earliest Eocene primate Teilhardina during the Paleocene-Eocene thermal maximum. Proceedings of the National Academy of Sciences of the United States of America, 103, 11223-11227. https://doi.org/10.1073/pnas.0511296103

Smith, T., Quesnel, F., De Ploëg, G., De Franceschi, D., Métais, G., De Bast, E., Solé, F., Folie, A., Boura, A., Claude, J., Dupuis, C., Gagnaison, C., Iakovleva, A., Martin, J., Maubert, F., Prieur, J., Roche, E., Storme, J. Y., Thomas, R., Tong, H., Yans, J. \& Buffetaut, E., 2014. First Clarkforkian equivalent Land Mammal Age in the latest Paleocene basal Sparnacian facies of Europe: fauna, flora, paleoenvironment and (bio)stratigraphy. PloS One, 9, e86229. https://doi.org/10.1371/journal.pone.0086229

Steurbaut, E., 1998. High-resolution holostratigraphy of Middle Paleocene to Early Eocene strata in Belgium and adjacent areas. Palaeontographica, Abteilung A, 247, 91-156.

Stidham, T.A., Lofgren, D., Farke, A.A., Paik, M. \& Choi, R., 2014. A lithornithid (Aves: Palaeognathae) from the Paleocene (Tiffanian) of southern California. PaleoBios, 31, 1-7.

Vandenberghe, N., Hilgen, F.J. \& Speijer, R. P. with contributions by Ogg, J.G., Gradstein, F.M., Hammer, O., Hollis, C.J. \& Hooker, J.J., 2012. The Paleogene period. In Gradstein, F.M., Ogg, J.G., Schmitz, M. \& Ogg, G. (eds), The Geologic Time Scale. Elsevier, Amsterdam, 855-921. https://doi.org/10.1016/B978-0-444-59425-9.00028-7

Wang, M., Mayr, G., Zhang, J. \& Zhou, Z., 2012. Two new skeletons of the enigmatic, rail-like avian taxon Songzia Hou, 1990 (Songziidae) from the early Eocene of China. Alcheringa, 36, 487-499. https://doi. org $/ 10.1080 / 03115518.2012 .673302$

Weidig, I., 2006. The first New World occurrence of the Eocene bird Plesiocathartes (Aves: ?Leptosomidae). Paläontologische Zeitschrift, 80, 230-237. https://doi.org/10.1007/BF02988439 